\title{
The epidemiology of conjunctival squamous cell carcinoma in Uganda
}

\section{R Newton*,', J Ziegler², C Ateenyi-Agaba², L Bousarghin ${ }^{3}$, D Casabonne', V Beral', E Mbidde'2, L Carpenter ${ }^{4}$,

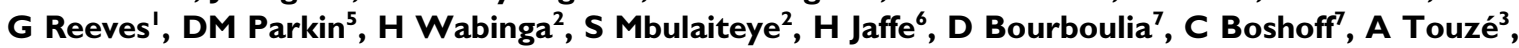 P Coursaget $^{3}$ and the Uganda Kaposi's Sarcoma Study Group ${ }^{8}$}

'Cancer Research UK, Epidemiology Unit, Gibson Building, Raddliffe Infirmary, Oxford OX2 6HE, UK; ${ }^{2}$ Uganda Cancer Institute and Makerere University Medical School, Kampala, Uganda; 'aboratoire de Virologie Moléculaire, INSERM EMIU 00-I0 and USC INRA, Faculté de Pharmacie, 37200 Tours, France; ${ }^{4}$ MRC Programme on AIDS, Uganda Virus Research Institute, PO Box 49, Entebbe, Uganda; ${ }^{5}$ International Agency for Research on Cancer, 150 Cours Albert-Thomas, Lyon, France; ${ }^{6}$ Centers for Disease Control and Prevention, 1600 Clifton Road, Atlanta, Georgia, GA 30333, USA; 7 Wolfson Institute of Medical Research, University College London, 46 Cleveland Street, London, UK

\begin{abstract}
As part of a larger investigation of cancer in Uganda, we conducted a case-control study of conjunctival squamous cell carcinoma in adults presenting at hospitals in Kampala. Participants were interviewed about social and lifestyle factors and had blood tested for antibodies to HIV, KSHV and HPV-16, -18 and -45. The odds of each factor among 60 people with conjunctival cancer was compared to that among 1214 controls with other cancer sites or types, using odds ratios, estimated with unconditional logistic regression. Conjunctival cancer was associated with HIV infection (OR 10.1, 95\% confidence intervals $[\mathrm{Cl}] 5.2-19.4 ; \mathrm{P}<0.00 \mathrm{I}$ ), and was less common in those with a higher personal income (OR 0.4, 95\% $\mathrm{Cl} 0.3-1.2$; $P<0.001$ ). The risk of conjunctival cancer increased with increasing time spent in cultivation and therefore in direct sunlight $\left(\chi^{2}\right.$ trend=3.9, $\left.P=0.05\right)$, but decreased with decreasing age at leaving home $\left(\chi^{2}\right.$ trend $\left.=3.9, P=0.05\right)$, perhaps reflecting less exposure to sunlight consequent to working in towns, although both results were of borderline statistical significance. To reduce confounding, sexual and reproductive variables were examined among HIV seropositive individuals only. Cases were more likely than controls to report that they had given or received gifts for sex (OR 3.5, 95\% Cl 1.2-10.4; $P=0.03$ ), but this may have been a chance finding as no other sexual or reproductive variable was associated with conjunctival cancer, including the number of self-reported lifetime sexual partners $(P=0.4)$. The seroprevalence of antibodies against HPV- 18 and -45 was too low to make reliable conclusions. The presence of anti-HPV- 16 antibodies was not significantly associated with squamous cell carcinoma of the conjunctiva (OR I.5, 95\% Cl 0.5-4.3; $P=0.5)$ and nor were anti-KSHV antibodies $(\mathrm{OR} 0.9,95 \% \mathrm{Cl} 0.4-$ 2.I; $P=0.8)$. The I0-fold increased risk of conjunctival cancer in HIV infected individuals is similar to results from other studies. The role of other oncogenic viral infections is unclear.

British Journal of Cancer (2002) 87, 30 I -308. doi:I0.I038/sj.bjc.660045I www.bjcancer.com

(C) 2002 Cancer Research UK
\end{abstract}

Keywords: conjunctival carcinoma; HIV; HPV; KSHV; HHV-8; Uganda

Squamous cell carcinoma of the conjunctiva is thought to be an extreme form of a spectrum of clinical conditions, collectively known as 'ocular surface squamous neoplasias', which range in severity from mild dysplasia, to carcinoma in situ and, ultimately, to invasive carcinoma. Symptoms can range from none, to severe pain and visual loss. Lesions generally arise on exposed areas of the eye, particularly on the nasal side, and treatment involves local excision, or in more severe cases, orbital clearance. Metastases are rare and the prognosis is usually favourable.

Although relatively rare everywhere, conjunctival carcinoma is more frequent in parts of sub-Saharan Africa. Uganda offers a good setting in which to investigate the epidemiology of squamous cell

\footnotetext{
*Correspondence: R Newton; E-mail: rob_newton@cancer.org.uk

${ }^{8}$ The Uganda Kaposi's Sarcoma Study Group includes named authors and V Sembajwe, M Kalinaki, R Byansi, C Rwatooro, S Nambooze, B Tushimiere, N Byabazaire (deceased), E Bitamazire, E Katabira, J Mugerwa (deceased), D Tindyebura, J Whitworth, B Richardson, R Weiss and K de Cock Received 8 February 2002; revised 19 April 2002; accepted 22 April 2002
}

carcinoma of the conjunctiva, because the tumour was relatively frequent there, even before the onset of the HIV epidemic (Templeton, 1973; Wabinga et al, 2000). In this report, we examine the association of conjunctival tumours with over 50 possible risk factors, including evidence of infection with HIV-1, HPV-16, -18 and -45 and Kaposi's sarcoma-associated herpesvirus (KSHV; human herpesvirus type 8 [HHV-8]), using data from a casecontrol study of cancer in adults (Ziegler et al, 1997; Newton et $a l, 2001)$.

\section{MATERIALS AND METHODS}

\section{Study subjects}

The subjects included in these analyses were selected from a large cross-sectional study of risk factors for cancer in Uganda, which included, in total, 2091 individuals with malignancies other than Kaposi's sarcoma. Between August 1994 and February 1998, any adults (aged 15 years and over) with a provisional new diagnosis of incident cancer were eligible for recruitment into the study from 
all the wards and out-patient clinics of the four main hospitals in Kampala, Uganda: Mulago (including the Uganda Cancer Institute), Nsambya, Mengo and Rubaga. Further details of the methods can be found elsewhere (Ziegler et al, 1997; Newton et al, 2001). The subjects included in this report are restricted to 60 cases of conjunctival cancer and 1214 controls. Thirty-two people with eye cancers that were not specifically diagnosed clinically as being squamous cell carcinomas, or had a pathological diagnosis of malignancy of uncertain morphology were excluded. The controls comprised people with other incident cancers, excluding those with cancer sites or types that are known to be associated with infection with HIV HPV or KSHV, or exposure to solar ultraviolet radiation - that is, Kaposi's sarcoma, non-Hodgkin's lymphoma, Hodgkin's disease, cancers of the uterine cervix, anus and penis, and skin cancers (IARC, 1992, 1995; Beral and Newton, 1998). The control group included men and women with cancers of the oral cavity (57), oesophagus (150), stomach (74), liver (103), breast (178), ovary (67), prostate (56), and other cancer sites or types (405). In addition, 124 patients with a provisional diagnosis of cancer, but who subsequently turned out to have benign tumours, were also included in the control group.

\section{Recruitment and questionnaire}

Interviewers (who were also trained HIV counsellors) approached ward or clinic staff to gain permission to interview potential recruits. If permission was granted, the patient was approached by one of four interviewers and invited to participate in the study. A HIV test was requested and appropriate counselling was given. Patients who had been HIV tested within a month of recruitment and had a medical certificate indicating the test result, were not retested. The patient was interviewed about social and demographic factors, and sexual and reproductive history. Where possible, the patient was interviewed by a counsellor of the same sex, and in their native language. Blood was drawn, primarily for the HIV test, but also for storage of serum and leukocytes. Interviewers reported the HIV test results back to the patient, together with post-test counselling. The study was approved by the Committee on Human Research (VA Medical Centre and University of California, San Francisco, CA, USA) and by the Uganda National Council for Science and Technology.

\section{Laboratory diagnoses}

Histology Diagnoses of cancer were established by histology or other laboratory investigation, where possible. Diagnoses made on clinical grounds alone, were reviewed by the investigators (C A-A, JZ, EM and SM). Among the cases, 36 (60\%) underwent histological review (all were invasive tumours) and the remainder were diagnosed clinically. Among controls, 63\% of tumour diagnoses were verified by laboratory investigation (histology, cytology, blood chemistry or ultrasound examination).

HIV-1 HIV-1 serostatus was determined using a single ELISA, the Cambridge Bioscience Recombigen enzyme linked immunosorbent assay (Cambridge, MA, USA). Periodic laboratory quality control assays using blinded standards from the United States Centers for Disease Control (Atlanta, GA, USA) revealed test sensitivity and specificity of $99 \%$. In the initial months of the study, $40-50 \%$ of adults declined to have venepuncture, mostly because they were too ill. Therefore, a GACELISA saliva test for HIV was introduced as an option (with sensitivity and specificity similar to the blood test), and the refusal rate dropped to $10 \%$. In total, HIV test results were available on 57 cases and 826 controls. However, for one case and seven controls the result was indeterminate. Any remaining aliquots of sera were stored at $-80^{\circ} \mathrm{C}$ and were later shipped on dry ice to the Laboratoire de Virologie Molé- culaire in Tours, France, for HPV testing and to University College London, UK, for KSHV testing.

$H P V-16,-18$ and -45 All assays were performed by a single investigator (LB), who was unaware of each patient's personal characteristics, and diagnosis. HPV VLPs were produced in Sf21 insect cells using recombinant baculoviruses encoding the L1 gene of HPV-16, -18 , and -45 , according to previously described procedures (Touzé et al; 1998; Combita et al, 2002a,b). These subtypes were chosen because they are known to be prevalent in tumour specimens from women with cancer of the uterine cervix in Uganda (Bosch et al, 1995). Briefly, the HPV L1 genes were first amplified from an HPV DNA-positive biopsy using primers containing BglII sites. The amplified product was then inserted into pFastBacI to generate HPV L1 VLPs. VLPs were produced according to a procedure used for HPV-16 VLPs (Touzé et al, 1998; El Mehdaoui et al, 2000). Sf 21 cells, maintained in Grace's insect medium supplemented with $10 \%$ foetal calf serum (FCS) were infected with the different recombinant baculoviruses at a m.o.i. of 10 and were incubated for $72 \mathrm{~h}$ at $27^{\circ} \mathrm{C}$. Cells were harvested by centrifugation, resuspended in PBS containing 0.5\% NP40 and allowed to stand at room temperature for $30 \mathrm{~min}$. Cell lysates were then centrifuged at $14000 \times \mathrm{g}$ for $15 \mathrm{~min}$ at $4^{\circ} \mathrm{C}$. The nuclear fractions were further re-suspended in ice cold PBS and sonicated by three $15 \mathrm{~s}$ bursts at 60\% maximal power (Vibra Cell, Bioblock Scientific, Strasbourg, France). Fractions were then loaded on the top of a preformed $\mathrm{CsCl}$ gradient and centrifuged at equilibrium in a Beckman SW28 rotor $\left(20\right.$ h, 27000 r.p.m., $\left.4^{\circ} \mathrm{C}\right)$. Gradient fractions were analysed for density by refractometry and were tested for the presence of L1 protein by ELISA. Immunoreactive fractions were finally pooled and pelleted by ultracentrifugation in a Beckman SW 28 rotor (3 h, 28000 r.p.m., $4^{\circ} \mathrm{C}$ ). VLPs were resuspended in PBS (pH 7.4) and protein content was evaluated using the microBCA kit (Pierce, Touzart et Matignon, France). Each preparation was tested for the presence of VLPs by electron microscopy. For this purpose, VLP preparations were applied to 400-mesh carbon-coated grids, negatively stained with $1.5 \%$ uranyl acetate and then examined at a nominal magnification of 50000 with a Jeol 1010 electron microscope. VLPs were then diluted in PBS and used in the following ELISA tests (Touzé et al, 1998; Combita et al, 2002a).

Flat-bottomed wells of 96-well microplates (Maxisorp, Nunc, Life Technologies, Eragny, France) were coated overnight at $4{ }^{\circ} \mathrm{C}$ with $200-400 \mathrm{ng}$ of VLPs (test well) or $200 \mathrm{ng}$ of BSA (control well) in PBS, pH 7.4. Each serum sample was tested twice against each of the seven VLP types and BSA at the same time on the same plate. After washing with PBS, $0.1 \%$ Tween 20 and $200 \mu \mathrm{l}$ of PBS containing $1 \%$ newborn bovine serum (NBS, Sigma, St Quentin Favallier, France) were added $\left(2 \mathrm{~h}\right.$ at $\left.37^{\circ} \mathrm{C}\right)$. The blocking solution was replaced by $100 \mu \mathrm{l}$ of sera diluted $1: 20$ in $5 x$ PBS-10\% NBS and $2 \%$ Tween 20 , and plates were incubated at $45^{\circ} \mathrm{C}$ for $60 \mathrm{~min}$. After four washes, bound antibodies were detected with a goat anti-human IgG immunoglobulin (diluted 1:5000) conjugated to horseradish peroxidase (Sigma). Following incubation at $45^{\circ} \mathrm{C}$ for $1 \mathrm{~h}$ and four washes, $100 \mu \mathrm{l}$ of a substrate solution containing ortho-phenylenediamine and $\mathrm{H}_{2} \mathrm{O}_{2}$ was added. After $30 \mathrm{~min}$ incubation, the reaction was stopped by addition of $100 \mu \mathrm{l}$ of $4 \mathrm{~N} \mathrm{H}_{2} \mathrm{SO}_{4}$, and optical densities (OD) were read at $492 \mathrm{~nm}$ with an automated plate reader (BioRad, model 550). For each serum sample the background reactivity found in the BSA coated wells was subtracted from the OD found in each of the HPV - VLP coated wells. Negative values were adjusted to zero. The cut-off values for positivity to HPV-16, -18 and -45 were set up at 0.2 (OD test well minus OD control well) and those with a value of 0.4 or greater were considered to have a high titre of anti-HPV antibodies. In total, 457 samples were available for testing for antibodies against HPV-16 (39 cases and 418 controls). In addition, there were sufficient sera for 453 of those to be tested for antibodies against HPV-18 and -45 (39 cases and 414 controls). 
KSHV All assays were performed by a single investigator (DB), who was unaware of each patient's personal characteristics, and diagnosis. A body-cavity-related B-cell lymphoma cell, BCP-1, which is positive for KSHV and negative for Epstein-Barr virus, was used for an indirect immunofluorescence assay to detect IgG antibodies against KSHV antigen (Gao et al, 1996; Boshoff et al, 1998). Latently infected BCP-1 cells were fixed in $4 \%$ paraformaldehyde and were made permeable with $0.2 \%$ Triton X-100. Cells were re-suspended in phosphate-buffered saline and fixed on glass slides. The samples were diluted $1: 100$ in phosphate-buffered saline with $3 \%$ foetal calf serum. The diluted serum was added to fixed BCP-1 cells and incubated at $22^{\circ} \mathrm{C}$ for $45 \mathrm{~min}$. After the slides were washed in phosphate-buffered saline with $3 \%$ foetal calf serum, rabbit antihuman IgG labelled with fluorescein isothiocyanate (Dako, High Wycombe, UK), diluted 1:40 in phosphate-buffered saline with $3 \%$ foetal calf serum, was added and the slides were incubated at $22^{\circ} \mathrm{C}$ for $20 \mathrm{~min}$. The slides were then washed in phosphate-buffered saline without foetal calf serum and screened by ultraviolet microscopy for the nuclear stippling pattern characteristic of antibodies against the latent nuclear antigen of KSHV encoded by orf73 (Gao et al, 1996). In total, 416 samples were available for testing for antibodies against KSHV ( 32 cases and 384 controls).

\section{Statistical methods}

Data were computerised by trained clerks using EPI-INFO-5 software, and statistical analyses were conducted using STATA 7.0 (Dean et al, 1990; STATA Corp, 2001). The odds ratio (OR) for each variable in cases versus controls, was estimated with unconditional logistic regression. All odds ratios were adjusted for age (15-24, $25-34,35-44$ and 45+), sex, HIV-1 sero-status and personal income (less than 20000 Uganda Shillings per year or $20000+$ Shillings). Additional adjustment was made for region of residence (Kampala or elsewhere), because most cases had been identified from outpatient clinics, which tend to draw patients from the local area, whereas controls had been hospital in-patients, who are from a wider area (Ziegler et al, 1997). These factors were selected a priori, with the exception of personal income, which was included following preliminary analyses. HIV infection is sexually transmitted and is strongly associated with many of the sexual and reproductive variables studied (data not shown). In order to avoid confounding, these factors were examined among HIV seropositive individuals only (there were too few HIV seronegative people to justify analysis). All $P$ values are two-sided. Note that numbers of cases and controls in the tables do not always add to the total, because of missing values.

\section{RESULTS}

Among those with conjunctival cancer, $43 \%$ (26 out of 60 ) were men and $57 \%$ (34 out of 60 ) were women. The proportion of all cancers comprising conjunctival carcinoma declined from $9 \%$ in those aged $15-24$ years to $2 \%$ in those over the age of 45 years. Seven per cent of cases and $5 \%$ of controls were born in Kampala, the remainder being born outside the capital city $(P=0.7)$ and, $41 \%$ of cases and $23 \%$ of controls reported their current residence as being in Kampala (Table 1; $P=0.13$ ). The seroprevalence of anti-HIV-1 antibodies was $70 \%$ among cases and 15\% among controls (Odds ratio [OR] 10.1, 95\% confidence intervals $[\mathrm{CI}] 5.2-19.4 ; P<0.001)$. The risk of conjunctival carcinoma was significantly lower among those with a high personal income (OR $0.4,95 \%$ CI $0.2-0.7 ; P<0.001$ ). For those who left home at ages $21+$ years (including those who never left), 15-20 years and $1-14$ years, the odds ratio was 1.0 (reference group), $0.7(0.4-1.5)$ and $0.4(0.2-1.0)$ respectively $\left(P_{\text {trend }}=0.05\right)$. Study participants were asked how long each week they spent cultivating, $0-9 \mathrm{~h}, 10-19 \mathrm{~h}$ or $20+\mathrm{h}$. The risk of conjunctival carcinoma increased significantly with increasing time spent cultivating (ORs 1.0, 1.9 and 2.4 respectively; $P_{\text {trend }}=0.03$ ).
Table I Distribution of region of birth, region of residence, tribe, nationality, HIV-I sero-status, income, age left home and time spent cultivating among cases with conjunctival carcinoma and controls with other cancers, in Uganda

\begin{tabular}{|c|c|c|}
\hline & $\begin{array}{l}\text { Number of } \\
\text { cases/controls }\end{array}$ & $\begin{array}{l}\text { Odds ratio and } 95 \% \\
\text { confidence intervals }\end{array}$ \\
\hline \multicolumn{3}{|l|}{ Region of birth } \\
\hline Kampala & $4 / 54$ & 1.0 \\
\hline \multirow{2}{*}{ Rest of Uganda } & $59 / 982$ & 1.2 \\
\hline & & $\chi^{2}$ heterogeneity $(I d f)=0.1 ; P=0.7$ \\
\hline \multicolumn{3}{|l|}{ Region of residence } \\
\hline Kampala & $25 / 272$ & 1.0 \\
\hline \multirow[t]{2}{*}{ Rest of Uganda } & $35 / 922$ & 0.6 \\
\hline & & $\chi^{2}$ heterogeneity $(I d f)=2.3 ; P=0.1$ \\
\hline \multicolumn{3}{|r|}{ 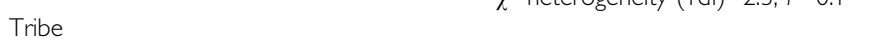 } \\
\hline Baganda & $27 / 631$ & 1.0 \\
\hline \multirow[t]{2}{*}{ Other } & $33 / 560$ & 1.4 \\
\hline & & $\chi^{2}$ heterogeneity $(I d f)=1.3 ; P=0.3$ \\
\hline \multicolumn{3}{|l|}{ Nationality } \\
\hline Ugandan & $56 / 1132$ & 1.0 \\
\hline \multirow{2}{*}{ Other } & $4 / 59$ & 1.4 \\
\hline & & $\chi^{2}$ heterogeneity $(I d f)=0.3 ; P=0.6$ \\
\hline \multicolumn{3}{|l|}{ HIV-I sero-status } \\
\hline Negative & $17 / 700$ & 1.0 \\
\hline \multirow[t]{2}{*}{ Positive } & $39 / 119$ & 10.1 \\
\hline & & $\chi^{2}$ heterogeneity $(I d f)=52.9 ; P<0.00 I$ \\
\hline \multicolumn{3}{|l|}{ Personal income $(\mathrm{SH})$} \\
\hline$<20,000$ & $30 / 408$ & 1.0 \\
\hline \multirow{2}{*}{$20,000+$} & 29/552 & 0.4 \\
\hline & & $\chi^{2}$ heterogeneity $(I d f)=9.5 ; P<0.00 I$ \\
\hline \multicolumn{3}{|l|}{ Household income $(\mathrm{SH})$} \\
\hline$<30,000$ & $33 / 485$ & 1.0 \\
\hline \multirow[t]{2}{*}{$30,000+$} & $22 / 419$ & 0.6 \\
\hline & & $\chi^{2}$ heterogeneity $(I d f)=1.9 ; P=0.2$ \\
\hline \multicolumn{3}{|l|}{ Age left home (years) } \\
\hline $21+$ (or never left) & $22 / 330$ & 1.0 \\
\hline $15-20$ & $26 / 375$ & 0.7 \\
\hline \multirow[t]{2}{*}{$1-14$} & $11 / 292$ & 0.4 \\
\hline & & $\chi^{2}$ trend $(I d f)=3.9 ; P=0.05$ \\
\hline \multicolumn{3}{|l|}{$\begin{array}{l}\text { Time spent cultivating } \\
\text { (Hours per week) }\end{array}$} \\
\hline $0-9$ & $9 / 241$ & 1.0 \\
\hline $10-19$ & $23 / 401$ & 1.9 \\
\hline \multirow[t]{2}{*}{$20+$} & $26 / 348$ & 2.4 \\
\hline & & $\chi^{2}$ trend $(I d f)=3.9 ; P=0.05$ \\
\hline
\end{tabular}

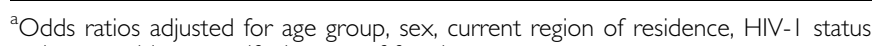
and personal income. $\mathrm{df}=$ degrees of freedom.

Table 2 shows the results for anti-HPV and KSHV antibodies. The seroprevalence of anti-HPV antibodies in controls was $10 \%$ for HPV-16 (43 out of 418), 4\% (16 out of 414) for HPV-18 and $6 \%$ (24 out of 414) for HPV-45. The corresponding results for those with conjunctival cancer were $21 \%$ (eight out of 39), $10 \%$ (four out of 39 ) and $5 \%$ (two out of 39) respectively. However, after adjustment for age, sex, address, HIV status and personal income, there were no statistically significant associations between the presence of anti-HPV-16, -18 and -45 antibodies and the risk of conjunctival carcinoma. Results for each HPV subtype were also calculated according to a measure of the antibody titre: the optical densities at each level correspond to less than 0.2 for negative, $0.2-0.39$ for medium titre and 0.4 or above for high titre. The numbers of cases and controls with anti-HPV antibodies to subtypes -18 and -45 were too few to yield any significant results. The results for anti-HPV-16 antibodies at each measure of titre were 1.0 (HPV-16 antibody negative, based on 31 cases and 375 controls), 0.7 (0.2-2.9; medium titre, based on four cases and 31 controls) and $6.3(1.2-33.4$; high titre, based on four cases 
Table 2 Comparison of human papillomavirus antibodies (HPV types I6, 18 and 45) and Kaposi's sarcoma-associated herpesvirus (KSHV) antibodies between those with conjunctival cancer and those without

\begin{tabular}{|c|c|c|}
\hline & $\begin{array}{l}\text { Number of } \\
\text { cases/controls }\end{array}$ & $\begin{array}{l}\text { Odds ratio and } 95 \% \\
\text { confidence intervals }\end{array}$ \\
\hline \multicolumn{3}{|l|}{ HPV-16 } \\
\hline Negative & $31 / 375$ & 1.0 \\
\hline Positive & $8 / 43$ & $\begin{array}{l}1.5(0.5-4.3) \\
\chi^{2} \text { heterogeneity }(\mathrm{Idf})=0.5 ; P=0.5\end{array}$ \\
\hline \multicolumn{3}{|r|}{$\begin{array}{l}a \\
\end{array}$} \\
\hline Negative & $35 / 398$ & 1.0 \\
\hline Positive & $4 / 16$ & $\begin{array}{l}2.3(0.5-9.6) \\
\chi^{2} \text { heterogeneity }(\mathrm{Idf})=1.2 ; P=0.3\end{array}$ \\
\hline \multicolumn{3}{|r|}{$x^{2}=0$} \\
\hline Negative & $37 / 390$ & 1.0 \\
\hline Positive & $2 / 24$ & $\begin{array}{l}0.4(0.1-2.1) \\
\chi^{2} \text { heterogeneity }(\mathrm{Idf})=1.5 ; P=0.2\end{array}$ \\
\hline \multicolumn{3}{|c|}{ HPV-16, - 18 or -45} \\
\hline All negative & $28 / 345$ & 1.0 \\
\hline Any positive & $11 / 69$ & $\begin{array}{c}1.3(0.5-3.2) \\
\chi^{2} \text { heterogeneity }(\mathrm{Idf})=0.4 ; P=0.6\end{array}$ \\
\hline \multicolumn{3}{|r|}{ 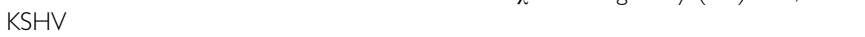 } \\
\hline Negative & $17 / 196$ & 1.0 \\
\hline Positive & $15 / 188$ & $\begin{array}{c}0.9(0.4-2.1) \\
\chi^{2} \text { heterogeneity }(\mathrm{Idf})=0.1 ; P=0.8\end{array}$ \\
\hline
\end{tabular}

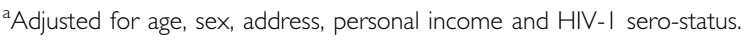

and 12 controls; $P_{\text {trend }}=0.2$ ). Only 15 people had anti-HPV antibodies to more than one tested HPV subtype (two cases and 13 controls) and there was no significant excess risk of the tumour in these individuals, as compared to those who were considered to be negative for all three subtypes (OR 0.6 , 95\% CI $0.1-4.3$ ). In relation to Kaposi's sarcoma-associated herpesvirus, the seroprevalence of anti-KSHV antibodies was $47 \%$ (15 out of 32) among cases and $49 \%$ (188 out of 384) among controls (OR 0.9, 95\% CI $0.4-2.1 ; P=0.8$ ).

Further results are provided in Appendices 1-4. Results for other social and demographic factors, none of which was associated with an increased risk of conjunctival carcinoma, are shown in Appendix 1. Factors, other than income, that might characterise wealth and social status in Uganda, such as ownership of livestock and travel away from home, are shown in Appendix 2. None of these variables were associated with conjunctival carcinoma. Appendix 3 shows results for other possible exposures. Those who reported having had a blood transfusion in the past were less likely to be cases (OR $0.4,95 \%$ CI $0.2-0.9 ; P=0.02$ ). Results for sexual and reproductive variables among HIV seropositive people only, are shown in Appendix 4. A self reported history of having either given or received gifts in exchange for sex was associated with an increased risk of the tumour (OR 3.5, 95\% CI 1.2-10.4; $P=0.03$ ), although this may have been a chance finding as there was no statistically significant association with any other sexual or reproductive variable, including the reported number of lifetime sexual partners $(P=0.4)$.

\section{DISCUSSION}

Here, we report an investigation of the epidemiology and aetiology of conjunctival squamous cell carcinoma, examining over 50 risk factors for the tumour. Conjunctival cancer affects relatively young individuals of both sexes and is strongly associated with HIV infection and poverty. In addition, the risk of the disease decreases with decreasing age at which an individual leaves home and with increasing time spent cultivating, although both results are of borderline statistical significance. Furthermore, significance tests were conducted on over 50 risk factors, greatly increasing the likelihood of significant results arising by chance alone. The role of HPV-16, -18 and -45 requires further evaluation, but KSHV does not appear to be associated with conjunctival carcinoma.

The study reported here is subject to the potential problems of incomplete diagnostic verification and HIV testing. Laboratory verification of cancer diagnosis (for example, by histology, cytology or blood chemistry) was available on $60 \%$ of cases (all of which were invasive tumours) and $63 \%$ of controls. Typical of studies in developing countries where laboratory services are limited, this proportion compares favourably with other cancer series reported from Africa (Bassett et al, 1995; Newton et al, 1996a; Wabinga et $a l, 2000)$. Another potentially important source of bias is the high proportion of adults who were not tested for HIV in the early stages of the study. However, the age and sex-specific seroprevalence rates of HIV infection among those tested is broadly similar to that found in studies of HIV seroprevalence in Uganda (STD/ AIDS Control Programme, Uganda, 1997). Also, the introduction of a saliva test resulted in a dramatic reduction in refusals, but little change in HIV seroprevalence rates, suggesting that patients who were refusing to have a HIV test were unwilling to have blood taken, rather than unwilling to learn their HIV serostatus. The association of conjunctival cancer with HIV infection has been reported in a general paper on HIV and cancer among residents of Kampala, and the odds ratio was the same as that from the current study of all patients who were seen at hospitals in Kampala (Newton et al, 2001). A proportion of individuals in the study were also tested for antibodies to three HPV subtypes and to KSHV infection. This additional testing occurred in all those for whom enough stored sera were available and (as people are unaware of their own status with respect to infection), is therefore an unbiased sample.

Another potential source of bias arises from the fact that most (but not all) cases had been identified from out-patient clinics, which tend to draw patients from the local area, whereas controls had been hospital in-patients, who are from a wider area. Despite adjusting for region of residence in the analyses, the possible impact of this on the results, is difficult to assess.

Case reports of squamous cell carcinoma of the conjunctiva in human immunodeficiency virus (HIV) infected men in the USA and France, coupled with a marked increase in the numbers of tumours being seen by ophthalmologists in at least two African centres (which mirrored the increases seen for Kaposi's sarcoma), led to the suggestion of an association with HIV (Winward and Curtin, 1989; Ateenyi-Agaba, 1995; Kestelyn et al, 1990; Kim et al, 1990; Denis et al, 1994). Among those with HIV, the lesions often affect young adults, in a fashion reminiscent of Kaposi's sarcoma in HIV-seropositive people (Ateenyi-Agaba, 1995; Kestelyn et al, 1990; Waddell et al, 1996). This study, together with others from Africa and the USA indicate about a 10-fold increased risk of the tumour in HIV infected, compared to HIV uninfected individuals (AteenyiAgaba, 1995; Kestelyn et al, 1990; Goedert and Coté, 1995; Newton et al, 1995, 2001; Waddell et al, 1996). Indeed, the spread of HIV in Uganda probably accounts for much of the approximately eightfold increase in incidence of conjunctival carcinoma observed there since the 1960s (Wabinga et al, 2000). Using standard equations for case-control studies, the population attributable fraction is about $60 \%$ : almost two-thirds of cases would not occur in the absence of HIV infection (dos Santos Silva, 1998). However, the frequency of conjunctival carcinoma is not such that it is yet a particularly common manifestation of HIV disease (Piot et al, 1992).

The mechanism whereby HIV infection increases the risk of conjunctival cancer is not clear. There is no evidence that it is directly oncogenic and the impact on cancer risk is most likely to be mediated via immunosuppression, as is the case for other HIV-associated cancers (Beral and Newton, 1998; Newton et al, 1999). It is not known if the risk of conjunctival squamous cell carcinoma is increased in other immunosuppressed groups, such 
as transplant recipients, because the tumour is very rare in parts of the world where tissue transplantation occurs. However, there is a case report of a conjunctival cancer in a patient with malignant lymphoma on immunosuppressive chemotherapy (Kushner and Mushen, 1975). In general, HIV infection is thought to increase cancer risk by facilitating the action of other oncogenic viruses, such as KSHV, the principal cause of Kaposi's sarcoma. In relation to conjunctival cancer however, we found no evidence in these data of an association with KSHV.

Several types of squamous carcinoma are associated with human papillomavirus (HPV) infection, most notably cancer of the uterine cervix, induced primarily by HPV-16, -18 and others. Squamous carcinoma of the skin has also been associated with HPV-5 and -8 in immunosuppressed individuals (IARC, 1995). Evidence for an association between human papillomavirus and squamous cell carcinoma of the conjunctiva is conflicting, although bovine papillomaviruses are thought to cause conjunctival carcinomas in cattle (IARC, 1995). The presence of human papillomavirus DNA (HPV; predominantly types 16 , but also other types) in human ocular surface squamous neoplasias, including invasive carcinomas, has been reported in some studies, but not others (reviewed by Newton, 1996). This is the first study to look for an association between anti-HPV antibodies (types $-16,-8$ and -45) and the risk of conjunctival carcinoma. The seroprevalence of antibodies against HPV-18 and -45 was too low to make reliable conclusions. Results for anti-HPV-16 antibodies were suggestive of an association among individuals with high titres, but the data presented here are too few to draw valid conclusions and studies of larger numbers of cases are required.

The HPV assays used in this study are based on the expression of L1 major capsid proteins of HPV-16, -18 and -45 in insect cells by using recombinant baculoviruses (Touzé et al, 1998). The resulting virus-like particles (VLPs), which appear similar to empty virions, can be used in serological studies to test for type specific immunological responses to viral capsid proteins, although there is evidence that a particular assay may cross react with related HPV subtypes (Combita et al, 2002b). Presence of anti-VLP antibodies is an indicator of past and current infection (Kirnbauer et al, 1994; Le Cann et al, 1995; Wideroff et al, 1995; Dillner et al, 1996). The utility of such assays has been demonstrated in previous studies of anti-HPV-16 antibodies in relation to the risk of cancer of the uterine cervix (Lehtinen et al, 1996; Dillner et al, 1997; Shah et al, 1997; Vonka et al, 1999; Hisada et al, 2001). Results from this study on the relationship between anti-HPV-16 antibodies and the risk of cancer of the uterine cervix are broadly comparable to those reported before and will be the subject of a separate report.

Although relatively rare everywhere, conjunctival carcinoma is more frequent in sub-Saharan Africa and other tropical areas than in temperate countries, leading to the hypothesis that it may be associated with exposure to solar ultraviolet radiation (Templeton, 1973; Clear, 1979). Geographical studies support this premise, in

\section{REFERENCES}

Ateenyi-Agaba C (1995) Conjunctival squamous cell carcinoma associated with HIV infection in Kampala, Uganda. Lancet i: 695-696

Bassett MT, Chokunonga E, Mauchaza B, Levy L, Ferlay J, Parkin DM (1995) Cancer in the African population of Harare, Zimbabwe in 1990-92. Int J Cancer 63: $29-36$

Beral V, Newton R (1998) Overview of the epidemiology of immunodeficiency associated cancers. Monogr Natl Cancer Inst 23: 1-6

Bosch FX, Manos MM, Munoz N, Sherman M, Jansen AM, Peto J, Schiffman MH, Moreno V, Kurman R, Shah KV The International Biological Study on Cervical Cancer (IBSCC) Study Group (1995) Prevalence of human papillomavirus in cervical cancer: a worldwide perspective. J Natl Cancer Inst 87: $796-802$ that the incidence of squamous carcinoma of the eye increases as exposure to ambient solar ultraviolet radiation increases. Levels of solar radiation are higher towards the equator and the incidence of conjunctival cancer increases by about $50 \%$ for each $10^{\circ}$ decline in latitude (Newton et al, 1996b; Sun et al, 1997). In addition, a single case-control study reported that the risk of ocular surface epithelial dysplasias is greatest in those reporting a past history of skin cancer, which is known to be caused by exposure to solar ultraviolet radiation (Lee et al, 1994). Time spent cultivating may indicate the time an individual spends in direct sunlight, and so the increasing risk with increasing time cultivating may reflect exposure to ultraviolet radiation. This variable may also reflect exposure to dust or dirt, and it has been hypothesised that ocular trauma could facilitate development of the tumour (Templeton, 1973; Margo and Groden, 1986). The lower risk among people who leave home at an earlier age may reflect migration to towns for work, where exposure to solar ultraviolet radiation could be less. The extent to which the higher risk among those of low income is measuring the previously mentioned exposures is not clear. The fact that cases are less likely than controls to have had a blood transfusion is probably an artefact of the control selection. Cases were generally seen as out-patients, whereas controls with other cancers were generally hospital in-patients. The latter may therefore be more likely to have had a transfusion as part of their medical care.

In summary, the current study gives independent support for the strong epidemiological evidence that solar ultraviolet radiation is an important cause of squamous cell carcinoma of the conjunctiva. Another established risk factor is HIV infection, although the mechanism whereby it increases the risk of conjunctival cancer is not clear. We find little evidence supporting the possible role of sexually transmitted forms of HPV in the aetiology of conjunctival cancer, but larger studies are required.

\section{ACKNOWLEDGEMENTS}

Support for this work was provided by Mulago Hospital and Makerere Medical School, Kampala, Uganda, the Imperial Cancer Research Fund (now Cancer Research UK), the United States Centers for Disease Control and Prevention (interagency agreement with the Department of Veterans Affairs), the International Agency for Research on Cancer, World Health Organisation, Lyon, France and the Ligue Contre le Cancer, France. J Ziegler was on secondment from the Department of Veterans Affairs and the University of California, San Francisco, CA, USA, to the International Agency for Research on Cancer, France. L Bousarghin was the recipient of a fellowship from the Région Centre, France. L Carpenter was on secondment from the Academic Department of Public Health, Oxford University, to the MRC Programme on AIDS, Entebbe, Uganda.
Boshoff C, Gao SJ, Healy LE, Matthews S, Thomas AJ, Coignet L, Warnke RA, Strauchen JA, Matutes E, Kamel OW, Moore PS, Weiss RA, Chang Y (1998) Establishing a KSHV+ cell line (BCP-1) from peripheral blood and characterising its growth in Nod/SCID mice. Blood 91: 1671-1679

Clear AS (1979) Solar keratosis, pterygium and squamous cell carcinoma of the conjunctiva in Malawi. Br J Ophthalmol 63: $102-109$

Combita AL, Bravo MM, Touzé A, Orozco O, Coursaget P (2002a) Serologic response to Human oncogenic papillomavirus types 16, 18, 31, 33, 39, 58 and 59 virus-like particles in Colombian women with invasive cervical cancer. Int J Cancer 97: 796-803 
Combita AL, Touzé A, Bousarghin L, Christensen ND, Coursaget P (2002b) Identification of two cross-neutralizing linear epitopes within the L1 major capsid protein of human papillomavirus. J Virol (in press).

Dean AD, Dean JA, Burton JH, Dicker RC (1990) Epi Info, Version 5: a word processing, database and statistics program for epidemiology on microcomputers. Centers for Disease Control, Atlanta, Georgia, USA.

Denis P, Charpentier D, Roudier M, Lemaire JC, Levin N, Nguyea-Khoa JL (1994) Conjunctival epidermoid carcinoma and human immunodeficiency virus. J Fr Ophtalmol 17: 366-369

Dillner JL, Kallings I, Brihmer C, Sikstrom B, Koskela P, Lehtinen M, Schiller JT, Sapp M, Mardh PA (1996) Seropositivities to human papillomavirus type 16,18 or 33 capsids and to Chlamydia trachomatis are markers of sexual behaviour. J Infect Dis 173: $1394-1398$

Dillner JL, Lehtinen M, Bjorge T, Luostarinen T, Youngman L, Jellum E, Koskela P, Gislefoss RE, Hallmans G, Paavonen J, Sapp M, Schiller JT, Hakulinen T, Thoresen S, Hakama M (1997) Prospective seroepidemiologic study of human papillomavirus infection as a risk factor for invasive cervical cancer. J Natl Cancer Inst 89: 1293 - 1299

El Mehdaoui S, Touzé A, Laurent S, Sizaret PY, Rasschaert D, Coursaget P (2000) Gene transfer using recombinant rabbit hemorrhagic disease virus capsids with genetically modified DNA encapsidation capacity by addition of packaging sequences from L1 or L2 protein of human papillomavirus type 16.. J Virol 74: $10332-10340$

Gao S-J, Kingsley L, Li M, Zheng W, Parravicini C, Ziegler JL, Newton R, Rinaldo CR, Saah A, Phair J, Detels R, Chang Y, Moore PS (1996) Seroprevalence of Kaposi's sarcoma-associated herpesvirus antibodies among Americans, Italians and Ugandans with and without Kaposi's sarcoma. Nature Med 2: $925-928$

Goedert JJ, Coté TR (1995) Conjunctival malignant disease with AIDS in USA. Lancet ii: $257-258$

Hisada M, van den Berg BJ, Strickler HD, Christianson RE, Wright WE Waters DJ, Rabkin CS (2001) Prospective study of antibody to human papillomavirus type 16 and risk of cervical, endometrial and ovarian cancers (United States). Cancer Causes Control 12: 335-341

IARC (1992) Monographs on the evaluation of carcinogenic risks to humans. Solar and Ultraviolet Radiation. IARC Monograph vol 55, Lyon

IARC (1995) Monographs on the evaluation of carcinogenic risks to humans Human papillomaviruses.. IARC Monograph vol 64, Lyon

Kestelyn P, Stevens AM, Ndayambaje A, Hanssens M, van de Perre P (1990) HIV and conjunctival malignancies. Lancet 336: 51-52

Kim RY, Seiff SR, Howes EL Jr, O’Donnell JJ (1990) Necrotizing scleritis secondary to conjunctival squamous cell carcinoma in aquired immunodeficiency syndrome. Am J Opthalmol, 109: 231-233

Kirnbauer R, Hubbert NL, Wheeler CM, Becker TM, Lowy DR, Schiller JT (1994) A virus-like particle enzyme-linked immunosorbent assay detects serum antibodies in a majority of women infected with human papillomavirus type-16. J Natl Cancer Inst 86: 494-499

Kushner FH, Mushen RL (1975) Conjunctival squamous cell carcinoma combined with malignant lymphoma. Am J Ophthalmol 80: 503-506

Le Cann P, Touzé A, Enogat N, Leboulleux D, Mougin C, Legrand MC, Calvet C, Afoutou JM, Coursaget P (1995) Detection of antibodies against human papillomavirus (HPV) type-16 virions by ELISA using recombinant HPV $16 \mathrm{~L} 1$ capsids produced by recombinant baculovirus. J Clin Microbiol 33: $1380-1382$

Lee GA, Williams G, Hirst LW, Green AC (1994) Risk Factors in the Development of Ocular Surface Epithelial Dysplasia. Ophthalmology 101: 360 364

Lehtinen M, Dillner J, Knekt P, Luostarinen T, Aromaa A, Kirnbauer R, Koskela P, Paavonen J, Peto R, Schiller JT, Hakama M (1996) Serologically diagnosed infection with human papillomavirus type 16 and risk for subsequent development of cervical carcinoma: nested case-control study. BMJ 312: $537-539$
Margo CE, Groden LR (1986) Squamous cell carcinoma of the cornea and conjunctiva following a thermal burn of the eye. Cornea 5: 185-188

Newton R, Grulich A, Beral V, Sindikubwabo B, Ngilimana P-J, Nganyira A, Parkin DM (1995) Cancer and HIV infection in Rwanda. Lancet i: 1378

Newton R (1996) A review of the aetiology of squamous cell carcinoma of the conjunctiva. Br J Cancer 74: $1511-1513$

Newton R, Ngilimana PJ, Grulich A, Beral V, Sindikubwabo B, Nganyira A, Parkin DM (1996a) Cancer in Rwanda. Int J Cancer 66: 75-81

Newton R, Ferlay J, Reeves G, Beral V, Parkin DM (1996b) Incidence of squamous cell carcinoma of the eye increases with increasing levels of ambient solar ultraviolet radiation. Lancet i: $1450-1451$

Newton R, Beral V, Weiss R (1999) Human immunodeficiency virus infection and cancer. In Cancer Surveys volume 33, Infections and Human Cancer, Newton R, Beral V, Weiss R (eds), pp 237-261. Cold Spring Harbor Laboratory Press

Newton R, Ziegler J, Beral V, Mbidde E, Carpenter L, Wabinga H, Mbulataiye S, Appleby P, Reeves G, Jaffe H and the Uganda Kaposi's Sarcoma Study Group (2001) A case-control study of Human Immunodeficiency Virus infection and cancer in adults and children residing in Kampala, Uganda. Intl J Cancer 92: 622-627

Piot P, Kapita BM, Ngugi E, Mann JM, Colebunders RL, Wabitsch R (1992) AIDS in Africa. A Manual for Physicains. WHO, Geneva

dos Santos Silva I (1998) Cancer Epidemiology Principles and Methods. IARC, Lyon

Shah KV, Viscidi RP, Alberg AJ, Helzlsouer KJ, Comstock GW (1997) Antibodies to human papillomavirus 16 and subsequent in situ or invasive cancer of the cervix. Cancer Epidemiol Biomarkers Prev 6: 233-237

STATA Corp (2001) Stata software, College Park, TX, USA

STD/AIDS Control Programme HIV/AIDS Surveillance Report, March. (1997) Ministry of Health, PO Box 8, Entebbe, Uganda

Sun EC, Fears TR, Goedert JJ (1997) Epidemiology of squamous cell conjunctival cancer. Cancer Epidemiol, Biomark Preven 6: 73-77

Templeton AC (1973) Tumours of the eye and adnexa. In Tumours of a Tropical Country: A survey of Uganda 1964-1968. Templeton AC (ed), pp 203-214 Recent Result Cancer Research

Touzé A, el Mehdaoui S, Sizaret PY, Mougin C, Munoz N, Coursaget P (1998) The L1 major capsid protein of Human Papillomavirus Type 16 variants affects the yield of virus-like particle produced in an insect cells expression system. J Clin Microbiol 36: 2046-2051

Vonka V, Hamsikova E, Kanka J, Ludvikova V, Sapp M, Smahel M (1999) Prospective study on cervical neoplasia IV. Presence of HPV antibodies. Int J Cancer 80: $365-368$

Wabinga HR, Parkin DM, Wabwire-Mangen F, Nambooze S (2000) Trends in cancer incidence in Kyadondo County, Uganda, 1960-1997. Br Cancer 82: $1585-1592$

Waddell KM, Lewallen S, Lucas SB, Ateenyi-Agaba C, Herrington CS, Liomba G (1996) Carcinoma of the conjunctiva and HIV infection in Uganda and Malawi. Br J Ophthalmol 80: 503-508

Wideroff L, Schiffman MH, Hoover R, Tarane TE, Nonnenmacher B, Hubbert NL, Kirnbauer R, Greer CE, Lorincz AT, Manos MM, Glass AG, Scott DR, Sherman ME, Buckland J, Lowy D, Schiller J (1995) Evaluation of sero-reactivity to human papillomavirus type 16 virus-like particles in an incident case-control study of cervical neoplasia. J Infect Dis 172: $1425-1430$

Winward KE, Curtin VT (1989) Conjunctival squamous cell carcinoma in a patient with human immunodeficiency virus infection. Am J Ophthalmol 107: $554-555$

Ziegler JL, Newton R, Katongole-Mbidde E, Mbulataiye S, DeCock K, Wabinga H, Mugerwa J, Katabira E, Jaffe H, Parkin DM, Reeves G, Beral V for the Uganda Kaposi's sarcoma study group (1997) Risk factors for HIV-associated Kaposi's sarcoma in Uganda: a case-control study of 1026 Adults. AIDS 11: $1619-1626$ 
Appendix I Comparison of social and demographic factors between people with and without conjunctival cancer

\begin{tabular}{|c|c|c|}
\hline & $\begin{array}{l}\text { Number of } \\
\text { cases/controls }\end{array}$ & $\begin{array}{l}\text { Odds ratio and } 95 \% \\
\text { confidence intervals }\end{array}$ \\
\hline \multicolumn{3}{|c|}{ Years at current address } \\
\hline$<10$ & $27 / 220$ & 1.0 \\
\hline \multirow[t]{2}{*}{$10+$} & $33 / 778$ & 0.8 \\
\hline & & $\chi^{2}$ heterogeneity $(I d f)=0.8 ; P=0.4$ \\
\hline \multicolumn{3}{|l|}{ Settlement type } \\
\hline I-99 houses & $29 / 704$ & 1.0 \\
\hline \multirow{2}{*}{$100+$ houses } & $31 / 287$ & 1.5 \\
\hline & & $\chi^{2}$ heterogeneity $(I d f)=1.7 ; P=0.2$ \\
\hline \multicolumn{3}{|l|}{ Travel time to market } \\
\hline$<30$ mins & $40 / 400$ & 1.0 \\
\hline \multirow{2}{*}{$30+$ mins } & $14 / 456$ & 0.6 \\
\hline & & $\chi^{2}$ heterogeneity $(I d f)=2.0 ; P=0.2$ \\
\hline \multicolumn{3}{|l|}{ Age left school } \\
\hline No school & $7 / 270$ & 1.0 \\
\hline$<15$ years & $25 / 289$ & 1.4 \\
\hline $16-19$ years & $20 / 262$ & 1.2 \\
\hline \multirow[t]{2}{*}{$20+$ years } & $8 / 163$ & 0.8 \\
\hline & & $\chi^{2}$ trend $(I d f)=0.4 ; P=0.5$ \\
\hline \multicolumn{3}{|l|}{ Education level } \\
\hline No school & $7 / 273$ & 1.0 \\
\hline Primary & 19/272 & 1.5 \\
\hline \multirow[t]{2}{*}{ Secondary/tertiary } & $34 / 450$ & 1.1 \\
\hline & & $\chi^{2}$ trend $(I d f)=0.7 ; P=0.4$ \\
\hline \multicolumn{3}{|l|}{ Religion } \\
\hline Christian & $55 / 882$ & 1.0 \\
\hline \multirow{2}{*}{ Muslim } & $5 / 125$ & 0.8 \\
\hline & & $\chi^{2}$ heterogeneity $(I d f)=0.2 ; P=0.7$ \\
\hline \multicolumn{3}{|l|}{ Occupation } \\
\hline \multirow{3}{*}{ Other } & |4/588 & 1.0 \\
\hline & $46 / 549$ & 1.7 \\
\hline & & $\chi^{2}$ heterogeneity $(I d f)=1.8 ; P=0.2$ \\
\hline \multicolumn{3}{|l|}{ Number in house } \\
\hline$<5$ & $25 / 383$ & 1.0 \\
\hline \multirow[t]{2}{*}{$5+$} & $35 / 621$ & 1.2 \\
\hline & & $\chi^{2}$ heterogeneity $(I d f)=0.3 ; P=0.6$ \\
\hline \multicolumn{3}{|l|}{ Number of siblings } \\
\hline$<5$ & $32 / 567$ & 1.0 \\
\hline \multirow[t]{2}{*}{$5+$} & $28 / 438$ & 0.8 \\
\hline & & $\chi^{2}$ heterogeneity $(I d f)=0.7 ; P=0.4$ \\
\hline \multicolumn{3}{|r|}{ 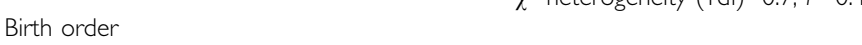 } \\
\hline $1-2$ & $25 / 467$ & 1.0 \\
\hline \multirow[t]{2}{*}{$3+$} & $35 / 538$ & 0.9 \\
\hline & & $\chi^{2}$ heterogeneity $(I d f)=0.1 ; P=0.7$ \\
\hline \multicolumn{3}{|l|}{ Number sharing toilet } \\
\hline$<6$ & 19/358 & 1.0 \\
\hline \multirow{2}{*}{$6+$} & $40 / 610$ & 1.1 \\
\hline & & $\chi^{2}$ heterogeneity $(I d f)=0.0 ; P=0.9$ \\
\hline
\end{tabular}

${ }^{a}$ Adjusted for age group, sex, address, personal income and HIV-I sero-status; $\mathrm{df}=$ degrees of freedom.
Appendix 2 Comparison of factors characterising wealth between those with and without conjunctival cancer

\begin{tabular}{|c|c|c|}
\hline & $\begin{array}{c}\text { Number of } \\
\text { cases/controls }\end{array}$ & $\begin{array}{l}\text { Odds ratio and } 95 \% \\
\text { confidence intervals }\end{array}$ \\
\hline \multicolumn{3}{|c|}{ Number of rooms in house } \\
\hline $1-2$ & $31 / 306$ & 1.0 \\
\hline \multirow[t]{2}{*}{$3+$} & $29 / 696$ & 0.8 \\
\hline & & $\chi^{2}$ heterogeneity $(I d f)=0.4 ; P=0.5$ \\
\hline \multicolumn{3}{|r|}{ מ } \\
\hline No & $38 / 770$ & 1.0 \\
\hline \multirow[t]{2}{*}{ Yes } & $21 / 228$ & 1.0 \\
\hline & & $\chi^{2}$ heterogeneity $(\mathrm{Idf})=0.0 ; P=1.0$ \\
\hline \multicolumn{3}{|c|}{ Own radio } \\
\hline No & $1 \mid / 205$ & 1.0 \\
\hline \multirow[t]{2}{*}{ Yes } & $49 / 794$ & 1.0 \\
\hline & & $\chi^{2}$ heterogeneity $(\mathrm{Idf})=0.0 ; P=0.9$ \\
\hline \multicolumn{3}{|c|}{ Own motorcar } \\
\hline No & $56 / 890$ & 1.0 \\
\hline \multirow[t]{2}{*}{ Yes } & $4 / 109$ & 0.5 \\
\hline & & $\chi^{2}$ heterogeneity $(\mathrm{Idf})=1.8 ; P=0.2$ \\
\hline \multicolumn{3}{|r|}{ 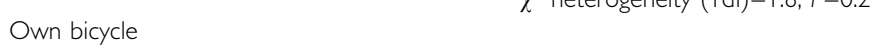 } \\
\hline No & $35 / 523$ & 1.0 \\
\hline \multirow[t]{2}{*}{ Yes } & $25 / 478$ & 1.0 \\
\hline & & $\chi^{2}$ heterogeneity $(\mathrm{Idf})=0.0 ; P=0.9$ \\
\hline \multicolumn{3}{|c|}{ Own cows } \\
\hline None & $50 / 736$ & 1.0 \\
\hline \multirow[t]{2}{*}{$1+$} & $9 / 259$ & 0.7 \\
\hline & & $\chi^{2}$ heterogeneity $(\mathrm{Idf})=0.7 ; P=0.4$ \\
\hline \multicolumn{3}{|c|}{ Own pigs and goats } \\
\hline None & $46 / 677$ & 1.0 \\
\hline \multirow{2}{*}{$1+$} & $14 / 319$ & 1.2 \\
\hline & & $\chi^{2}$ heterogeneity $(\mathrm{Idf})=0.3 ; P=0.6$ \\
\hline \multicolumn{3}{|c|}{ Own chickens } \\
\hline & $38 / 542$ & 1.0 \\
\hline & $22 / 431$ & 1.1 \\
\hline & & $\chi^{2}$ heterogeneity $(I d f)=0.1 ; P=0.8$ \\
\hline \multirow{2}{*}{\multicolumn{3}{|c|}{$\begin{array}{l}\text { Travel away from home > } \\
7 \text { nights per year }\end{array}$}} \\
\hline & & \\
\hline No & $53 / 877$ & 1.0 \\
\hline \multirow[t]{2}{*}{ Yes } & $7 / 105$ & 1.3 \\
\hline & & $\chi^{2}$ heterogeneity $(\mathrm{Idf})=0.2 ; P=0.7$ \\
\hline
\end{tabular}

adjusted for age group, sex, address, personal income and HIV-I sero-status; $\mathrm{df}=$ degrees of freedom 
Appendix 3 Comparison of other exposures between those with and without conjunctival cancer

\begin{tabular}{|c|c|c|}
\hline & $\begin{array}{c}\text { Number of } \\
\text { cases/controls }\end{array}$ & $\begin{array}{l}\text { Odds ratio and } 95 \% \\
\text { confidence intervals }\end{array}$ \\
\hline \multicolumn{3}{|l|}{ Use of shoes } \\
\hline Never/rarely & $26 / 619$ & 1.0 \\
\hline \multirow{2}{*}{ Often/always } & $33 / 372$ & 1.5 \\
\hline & & $\chi^{2}$ heterogeneity $(I d f)=1.5 ; P=0.2$ \\
\hline \multicolumn{3}{|c|}{ Age first use shoes (years) } \\
\hline$<15$ & $36 / 423$ & 1.0 \\
\hline \multirow{2}{*}{$15+$} & $23 / 532$ & 1.1 \\
\hline & & $\chi^{2}$ heterogeneity $(I d f)=0.1 ; P=0.7$ \\
\hline \multicolumn{3}{|l|}{ Soil colour } \\
\hline Black & $36 / 549$ & 1.0 \\
\hline \multirow{2}{*}{ Other } & $16 / 343$ & 1.0 \\
\hline & & $\chi^{2}$ heterogeneity $(I d f)=0.0 ; P=0.9$ \\
\hline \multicolumn{3}{|l|}{$\begin{array}{l}\text { Time spent in water } \\
\text { (hours per week) }\end{array}$} \\
\hline$<$ I hour & $47 / 728$ & 1.0 \\
\hline \multirow{2}{*}{$1+$ hours } & $12 / 272$ & 0.6 \\
\hline & & $\chi^{2}$ heterogeneity $(I d f)=2.9 ; P=0.1$ \\
\hline \multicolumn{3}{|r|}{$\begin{array}{l}a \\
\end{array}$} \\
\hline Never smoker & $46 / 762$ & 1.0 \\
\hline Ex-smoker & $7 / 146$ & 0.9 \\
\hline \multirow{2}{*}{ Current smoker } & $7 / 91$ & 1.1 \\
\hline & & $\chi^{2}$ heterogeneity $(I d f)=0.0 ; P=1.0$ \\
\hline \multicolumn{3}{|l|}{ Use of snuff } \\
\hline No & $58 / 977$ & 1.0 \\
\hline \multirow{2}{*}{ Yes } & $2 / 16$ & 2.0 \\
\hline & & $\chi^{2}$ heterogeneity $(I d f)=0.6 ; P=0.4$ \\
\hline \multicolumn{3}{|c|}{ Drink home-brewed alcohol } \\
\hline No & $36 / 533$ & 1.0 \\
\hline About once/week & $6 / 155$ & 0.4 \\
\hline 2-4/week & $8 / 131$ & 1.0 \\
\hline \multirow{2}{*}{ Most days } & $9 / 178$ & 0.9 \\
\hline & & $\chi^{2}$ heterogeneity $(\mathrm{Idf})=3.3 ; P=0.3$ \\
\hline \multicolumn{3}{|l|}{ Blood transfusion } \\
\hline No & $53 / 184$ & 1.0 \\
\hline \multirow{2}{*}{ Yes } & $7 / 183$ & 0.4 \\
\hline & & $\chi^{2}$ heterogeneity $(I d f)=5.6 ; P=0.02$ \\
\hline \multicolumn{3}{|c|}{$\begin{array}{l}\text { Injection from traditional } \\
\text { healer }\end{array}$} \\
\hline & $39 / 596$ & 1.0 \\
\hline \multirow{2}{*}{ Yes } & $21 / 374$ & 1.0 \\
\hline & & $\chi^{2}$ heterogeneity $(\mathrm{Idf})=0.0 ; P=0.9$ \\
\hline
\end{tabular}

$\overline{{ }^{a} \text { Odds ratios adjusted for age, sex, address, personal income and HIV-I sero-status. }}$
Appendix 4 Comparison of sexual and reproductive variables between those with conjunctival cancer and those without, among HIV seropositive individuals only

\begin{tabular}{|c|c|c|}
\hline & $\begin{array}{l}\text { Number of } \\
\text { cases/controls }\end{array}$ & $\begin{array}{l}\text { Odds ratio and } 95 \% \\
\text { confidence intervals }\end{array}$ \\
\hline \multicolumn{3}{|l|}{ Marital status } \\
\hline Single & $1 / 10$ & 1.0 \\
\hline Monogomous married & $22 / 43$ & 8.2 \\
\hline Polygamous married & $9 / 22$ & 9.8 \\
\hline Widower & $4 / 26$ & 3.3 \\
\hline \multirow[t]{2}{*}{ Separated } & $3 / 10$ & 4.2 \\
\hline & & $\chi^{2}$ heterogeneity $(\mathrm{Idf})=6.6 ; P=0.16$ \\
\hline \multicolumn{3}{|l|}{ Age first sex } \\
\hline$<18$ years & $26 / 65$ & 1.0 \\
\hline \multirow{2}{*}{$18+$ years } & $13 / 46$ & 0.7 \\
\hline & & $\chi^{2}$ heterogeneity $(I d f)=0.8 ; P=0.4$ \\
\hline \multicolumn{3}{|l|}{ Number of children } \\
\hline $0-2$ & $13 / 23$ & 1.0 \\
\hline $3-4$ & $9 / 25$ & 0.7 \\
\hline $5-6$ & $9 / 20$ & 1.0 \\
\hline \multirow[t]{2}{*}{$7+$} & $5 / 30$ & 0.5 \\
\hline & & $\chi^{2}$ trend $(I d f)=0.4 ; P=0.5$ \\
\hline \multicolumn{3}{|l|}{$\begin{array}{l}\text { Children with different } \\
\text { mothers or fathers }\end{array}$} \\
\hline No & $13 / 40$ & 1.0 \\
\hline \multirow[t]{2}{*}{ Yes } & $21 / 53$ & 1.4 \\
\hline & & $\chi^{2}$ heterogeneity $(\mathrm{Id} f)=0.5 ; P=0.5$ \\
\hline \multicolumn{3}{|l|}{ No. sexual partners } \\
\hline $1-4$ & $13 / 50$ & 1.0 \\
\hline $5-7$ & $10 / 17$ & 2.7 \\
\hline \multirow[t]{2}{*}{$8+$} & $16 / 40$ & 1.8 \\
\hline & & $\gamma^{2}$ trend $(I d f)=0.8: P=0.4$ \\
\hline \multicolumn{3}{|l|}{ History sexual discharge } \\
\hline No & $13 / 48$ & 1.0 \\
\hline \multirow[t]{2}{*}{ Yes } & $26 / 64$ & 1.9 \\
\hline & & $\chi^{2}$ heterogeneity $(\mathrm{Id} f)=2.1 ; P=0.2$ \\
\hline \multicolumn{3}{|l|}{ Gifts for sex } \\
\hline Never & $29 / 101$ & 1.0 \\
\hline \multirow[t]{2}{*}{ Ever } & $10 / 11$ & 3.5 \\
\hline & & $\chi^{2}$ heterogeneity $(\mathrm{Idf})=5.0 ; P=0.03$ \\
\hline \multicolumn{3}{|l|}{ Use condoms } \\
\hline Never & $28 / 83$ & 1.0 \\
\hline \multirow[t]{2}{*}{ Ever } & $11 / 28$ & 0.7 \\
\hline & & $\chi^{2}$ heterogeneity $(\mathrm{Id} f)=0.5 ; P=0.5$ \\
\hline \multicolumn{3}{|l|}{ Circumcised (men) } \\
\hline No & $17 / 34$ & 1.0 \\
\hline \multirow[t]{2}{*}{ Yes } & $0 / 7$ & 0.0 \\
\hline & & $\chi^{2}$ heterogeneity $(\mathrm{Id} f)=1.3 ; P=0.3$ \\
\hline \multicolumn{3}{|l|}{ Labial elongation (women) } \\
\hline No & $5 / 17$ & 1.0 \\
\hline \multirow[t]{2}{*}{ Yes } & $|6 / 5|$ & 0.9 \\
\hline & & $\gamma^{2}$ heterogeneity $(I d f)=0.1: P=0.8$ \\
\hline
\end{tabular}

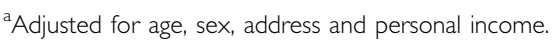

